\title{
Regulation of the VHL/HIF-1 Pathway by DJ-1
}

\author{
Mohammad Parsanejad, ${ }^{1}$ Yi Zhang, ${ }^{1}$ Dianbo Qu, ${ }^{1}$ Isabella Irrcher, ${ }^{1,3}$ Maxime W.C. Rousseaux, ${ }^{1}$ Hossein Aleyasin, ${ }^{1}$ \\ Fatemeh Kamkar, ${ }^{1}$ Steve Callaghan, ${ }^{1}$ Ruth S. Slack, ${ }^{1}$ Tak W. Mak, ${ }^{4}$ Stephen Lee, ${ }^{1}{ }^{-}$Daniel Figeys, ${ }^{2}$ and David S. Park ${ }^{1,5}$ \\ ${ }^{1}$ Department of Cellular and Molecular Medicine, ${ }^{2}$ Institute of Systems Biology, University of Ottawa, Ottawa, Ontario K1H 8M5, Canada, ${ }^{3}$ Department of \\ Ophthalmology, Queen's University, Kingston, Ontario K7L 5G2, Canada, ${ }^{4}$ The Campbell Family Institute for Breast Cancer Research, Toronto, Ontario \\ M5G 2C1, Canada, and 5epartment of Cogno-Mechatronics Engineering, Pusan National University, Busan 609-735, Korea
}

DJ-1 (PARK7) is a gene linked to autosomal recessive Parkinson disease (PD). We showed previously that DJ-1 loss sensitizes neurons in models of PD and stroke. However, the biochemical mechanisms underlying this protective role are not completely clear. Here, we identify Von Hippel Lindau (VHL) protein as a critical DJ-1-interacting protein. We provide evidence that DJ-1 negatively regulates VHL ubiquitination activity of the $\alpha$-subunit of hypoxia-inducible factor-1 (HIF-1 $\alpha$ ) by inhibiting HIF-VHL interaction. Consistent with this observation, $D J-1$ deficiency leads to lowered HIF-1 $\alpha$ levels in models of both hypoxia and oxidative stress, two stresses known to stabilize HIF- $1 \alpha$. We also demonstrate that HIF- $1 \alpha$ accumulation rescues $D J-1$-deficient neurons against 1-methyl-4-phenylpyridinium-induced toxicity. Interestingly, lymphoblast cells extracted from DJ-1-related PD patients show impaired HIF-1 $\alpha$ stabilization when compared with normal individuals, indicating that the DJ-1-VHL link may also be relevant to a human context. Together, our findings delineate a model by which DJ-1 mediates neuronal survival by regulation of the VHL-HIF-1 $\alpha$ pathway.

Key words: DJ-1; oxidative stress; Parkinson's disease

\section{Introduction}

Parkinson's disease (PD) is a neurodegenerative disorder, pathologically characterized by progressive loss of dopaminergic (DA) neurons in the substantia nigra pars compacta (SNc). While most cases are sporadic, $5-10 \%$ of the cases are familial and monogenic. Loss of $D J-1$ leads to an early-onset form of PD (Bonifati et al., 2003). We have previously shown that DA neurons in DJ-1deficient mice exhibit hypersensitivity to oxidative stress induced by 1-methyl-4-phenyl-1,2,3,6-tetrahydropyridine (MPTP), $\mathrm{H}_{2} \mathrm{O}_{2}$, and 1-methyl-4-phenylpyridinium $\left(\mathrm{MPP}^{+}\right)$, the active metabolite of MPTP (Kim et al., 2005). We and others have also shown that reactive oxygen species (ROS) is increased in cells/mice lacking DJ-1 (Taira et al., 2004; Aleya-

\footnotetext{
Received March 20, 2013; revised May 4, 2014; accepted May 5, 2014.

Author contributions: M.P., D.Q., M.W.C.R., H.A., R.S.S., T.W.M., S.L., and D.S.P. designed research;M.P., Y.Z., I.I., S.C., and D.F. performed research; D.Q., F.K., S.C., T.W.M., S.L., and D.F. contributed unpublished reagents/analytic tools; M.P. analyzed data; M.P., Y.Z., and D.S.P. wrote the paper.

This work was supported by grants from the Canadian Institutes of Health Research, Heart and Stroke Foundation of Ontario, Parkinson's Society Canada, Parkinson's Research Consortium, Neuroscience Canada/Krembil Foundation, and the Centre for Stroke Recovery. This work also was supported by the World Class University program through the National Research Foundation of Korea, funded by the Ministry of Education, Science and Technology, South Korea (Grant R31-2008-000-20004-0; to D.S.P.). The authors thank Alexander Revello and Dr. Yasmilde Rodriguez Gonzalez, University of Ottawa, Ontario, Canada, for their technical assistance. Authors would also like to thank Dr. Patrizia Rizzu, Medical Genomics VU University Medical Center, The Netherlands, for kindly providing human lymphoblasts.

Daniel Figeys is a Canada Research Chair in Proteomics and Systems Biology.

Correspondence should be addressed to David S. Park, Ottawa Health Research Institute, Neuroscience Group, University of Ottawa, 451 Smyth Road, 0ttawa, Ontario K1H 8M5, Canada. E-mail: dpark@uottawa.ca.

M.W.C.R.'s present address: Department of Molecular and Human Genetics, Baylor College of Medicine, Houston, Texas 77030.

H.A.'s present address: Fishberg Department of Neuroscience and Friedman Brain Institute, Icahn School of Medicine at Mount Sinai, New York, New York 10029-6574.

DOI:10.1523/JNEUROSCI.1244-13.2014

Copyright $\odot 2014$ the authors $\quad 0270-6474 / 14 / 338043-08 \$ 15.00 / 0$
}

sin et al., 2007). In line with this observation, numerous studies demonstrated that DJ-1 is neuroprotective under oxidative conditions (Aleyasin et al., 2007, 2010; Lee et al., 2009). The mechanisms through which DJ-1 exerts its antioxidantneuroprotective role are largely unclear.

To identify potential DJ-1-interacting proteins, we performed an unbiased mass spectrometry screen, which indicated Von Hippel Lindau (VHL) protein as a potential interacting partner. VHL is primarily a tumor-suppressor protein (Lonser et al., 2003) and its best-known biochemical role is as an E3 ubiquitinligase complex (Lonergan et al., 1998). One of the best-defined substrates of VHL is the $\alpha$-subunit of hypoxia-inducible factor- 1 (HIF-1 $\alpha$ ), a transcription factor important in the hypoxic response (Kamura et al., 2000; Tanimoto et al., 2000). Under normal levels of oxygen or ROS, HIF- $1 \alpha$ is hydroxylated by prolyl-hydroxylase proteins (PHDs; Berra et al., 2003), ubiquitinated by VHL protein, and finally degraded by the proteasome. Hypoxia or increased levels of ROS, however, inhibit PHD, which in turn inhibits VHL-mediated degradation of HIF- $1 \alpha$ and induces transcription of genes involved in cellular adaptation to hypoxic and oxidative stress condition, such as vascular endothelial growth factor (VEGF) and erythropoietin (EPO). Interestingly, HIF- $1 \alpha$ expression and its downstream targets are downregulated in the SNc of PD brains (Elstner et al., 2011). Conversely, increase of HIF- $1 \alpha$ and/or its targets are protective in several models of PD (Genc et al., 2002; Lee et al., 2009). HIF-1 $\alpha$ also upregulates tyrosine hydroxylase and increases dopamine release in PC12 cells and rat ventral mesencephalic cells (Johansen et al., 2010). Given these links of HIF-1 $\alpha$ to PD and our observations that VHL could potentially interact with DJ-1, we explored whether DJ-1 could regulate the VHL-HIF pathway. Presently, we provide evidence to support a model by which DJ-1 
regulates the ability of VHL to interact with and ubiquitinate HIF- $1 \alpha$ with consequences to neuronal survival in vitro.

\section{Materials and Methods}

Immunoprecipitation and Western blot analyses. SH-SY5Y cells were lysed in lysis buffer $(50 \mathrm{~mm}$ Tris $\mathrm{HCl}, \mathrm{pH} 7.5,100 \mathrm{~mm} \mathrm{NaCl}, 1$ mm EDTA, 1 mм DTT, $0.2 \%$ NP-40, and protease inhibitor). Endogenous VHL was pulled down by VHL antibody (BD Biosciences) and mouse IgG-conjugated beads (Trueblot system, eBiosciences) and analyzed by Western blot using VHL (BD Biosciences) and DJ-1 (Abcam) antibodies. In addition, SH-SY5Y cells were infected with adenovirus expressing FLAGVHL-GFP and exposed to $25 \mu_{\mathrm{M} \mathrm{H}} \mathrm{O}_{2}$ for $24 \mathrm{~h}$, then lysed in lysis buffer. The lysate (cleared of cell debris) was incubated with FLAG antibody overnight. Protein-antibody complexes were pulled down by mouse IgGconjugated beads (eBiosciences) and analyzed by Western blot using VHL and DJ-1 antibodies. Western blot analyses of cortical neurons, mouse embryonic fibroblasts (MEFs), or human lymphoblasts were performed as previously described (Qu et al., 2007), using antibodies for HIF-1 $\alpha$ (Cayman Chemical), VHL (BD Biosciences), DJ-1 (Abcam), $\beta$-actin (Sigma-Aldrich), ubiquitin (Abcam), and GST (Santa Cruz Biotechnology).

Semiquantitative and quantitative reverse-transcription PCR. Cortical neurons from primary cultures were harvested in Trizol and their total RNA was extracted based on Invitrogen protocols and $60 \mathrm{ng}$ of extracted RNA was used for each reaction. Reactions were performed using SYBR Green for quantitative reverse-transcription PCR (qRT-PCR) and SuperScript One-Step RT-PCR kit with Platinum Taq (Invitrogen) for semiquantitative RT-PCR. The programs designed for qRT-PCR included cDNA synthesis, $48^{\circ} \mathrm{C}$ for $30 \mathrm{~min}$; initial denaturation, $95^{\circ} \mathrm{C}$ for $10 \mathrm{~min}$; amplification of $H I F-1 \alpha$ and GAPDH, 40 cycles of $95^{\circ} \mathrm{C}$ for $15 \mathrm{~s}, 61.5^{\circ} \mathrm{C}(H I F-1 \alpha)$ or $57^{\circ} \mathrm{C}$ (for GAPDH) for $30 \mathrm{~s}$, and $72^{\circ} \mathrm{C}$ for 30 s. The primers used for amplification of $H I F-1 \alpha$ were $5^{\prime}$ ccgggggaggacgatgaaca- $3^{\prime}$ and $5^{\prime}$-tgaatatggcccgtgcagtgaagc- $3^{\prime}$, and for amplification of $G A P D H$ were $5^{\prime}$-ggtgaaggtcggtgtgaacg- $3^{\prime}$ and $5^{\prime}$ ctcgctcctggaagatggtc- $3^{\prime}$. The programs designed for RT-PCR were as follows: cDNA synthesis, $48^{\circ} \mathrm{C}$ for $45 \mathrm{~min}$; initial denaturation, $94^{\circ} \mathrm{C}$ for 2 min; amplification of the target genes, 28 (HIF-1 $\alpha$ and VEGF) or 26 (S12) cycles of $94^{\circ} \mathrm{C}$ for $30 \mathrm{~s}, 59^{\circ} \mathrm{C}(H I F-1 \alpha)$ or $60^{\circ} \mathrm{C}$ (VEGF and S12) for $30 \mathrm{~s}$, and $72^{\circ} \mathrm{C}$ for $1 \mathrm{~min}$. Primers used for amplification of the target genes were as follows: HIF-1 $\alpha, 5^{\prime}$-ctaacaagccgggggaggac- $3^{\prime}$ and $5^{\prime}$ tgtggctgggagttcttcgtatta- $3^{\prime}$ to generate a 476 bp product; VEGF, $5^{\prime}$ gacttgtgttgggaggagga- $3^{\prime}$ and $5^{\prime}$-cgtgtttctggaagtgagca- $3^{\prime}$ to produce a 161 bp product; $S 12,5^{\prime}$-ggaaggcatagctgctgg- $3^{\prime}$ and $5^{\prime}$-cctcgatgacatccttgg- $3^{\prime}$. After resolving the RT-PCR products on a $1.5 \%$ agarose-ethidium bromide gel, the signal density of the obtained bands were analyzed by densitometry. The signal density of the target bands were normalized against those of S12 and then control values (untreated control for each experiment) and were reported as fold increase in signal density of the target gene in reference to untreated control from the same experiment. Data are presented as mean $\pm \operatorname{SEM}(n=3)$.

In vitro and in vivo ubiquitination assay. To assess VHL ubiquitination activity, in vitro ubiquitination assay was performed as previously described (Kamura et al., 2000), with minor modifications. Briefly, $\approx 5 \mu \mathrm{g}$ aliquots of purified FLAG-VHL-GFP complex (purified as described above) were incubated with $\approx 0.3 \mu$ g of Ubal, $\approx 0.6 \mu \mathrm{g}$ of hUbc $5 \mathrm{a}, \approx 50$ $\mu \mathrm{g}$ of ubiquitin, $\approx 0.5 \mu \mathrm{g}$ of GST-HIF- $1 \alpha$, and $\approx 0.5 \mu \mathrm{g}$ of purified HisDJ-1 in $40 \mu \mathrm{l}$ of reaction buffer (40 mM HEPES-NaOH, pH 7.9, $60 \mathrm{~mm}$ potassium acetate, $2 \mathrm{~mm}$ DTT, $5 \mathrm{~mm} \mathrm{MgCl}_{2}, 0.5 \mathrm{~mm}$ EDTA, pH 7.9, 10\% glycerol, and $2 \mathrm{~mm} \mathrm{ATP}$ ) at $30^{\circ} \mathrm{C}$ for $2 \mathrm{~h}$. GST-HIF- $1 \alpha$ was immunoprecipitated from the reaction mixture by glutathione Sepharose and equal amounts of protein complexes were subjected to SDS-PAGE analysis. To assess its ubiquitination and VHL-interaction level, the Western blot membrane was probed with ubiquitin and VHL antibody respectively.
B

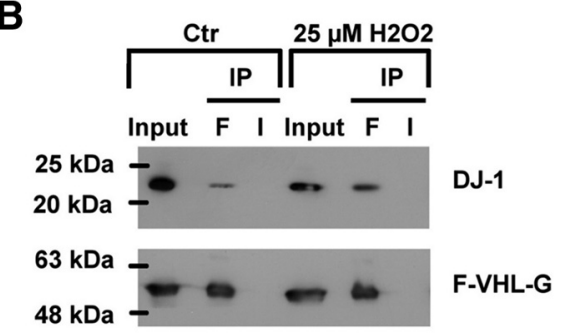

VHL

Figure 1. DJ-1 interacts with VHL. $A$, SH-SY5Y cells were lysed and endogenous VHL was immunoprecipitated with VHL antibody and analyzed by Western blot using DJ-1 antibody. B, SH-SY5Y cells expressing FLAG-VHL-GFP (F-VHL-G) were treated with $25 \mu \mathrm{M} \mathrm{H} \mathrm{H}_{2} \mathrm{O}_{2}$, then lysed. FLAG-VHL-GFP was immunoprecipitated with FLAG antibody and subjected to SDS-PAGE analysis using DJ-1 antibody. F, FLAG antibody; I, IgG control.

For in vivo ubiquitination assay, wild-type or DJ-1-null fibroblasts (MEFs) were treated with $20 \mu \mathrm{M}$ MG-132 plus hypoxia (1\% oxygen) or MG-132 alone as control for $1 \mathrm{~h}$, and extracted proteins were analyzed by Western blot analysis, using HIF- $1 \alpha$ antibody. The amount of reduction of ubiquitinated HIF- $1 \alpha$ in response to hypoxia is considered as a measure of VHL activity.

Hypoxia, $\mathrm{MPP}^{+}$treatment, and survival assessment. Cortical neurons were obtained from wild-type (WT) or DJ-1-null embryos of either sex as described previously (Kim et al., 2005; Qu et al., 2007). Seventy-two hours after plating cortical neurons, half of their media was removed and the dishes, with no lid on, were transferred to hypoxia chamber $\left(1 \% \mathrm{O}_{2}\right)$. For survival experiments, $48 \mathrm{~h}$ after plating, cortical neurons were treated with $0.1 \mathrm{~mm}$ DMOG for $2 \mathrm{~h}$. Cells were then incubated with $20 \mu \mathrm{M} \mathrm{MPP}{ }^{+}$ for $48 \mathrm{~h}$ (Qu et al., 2007; Huang et al., 2010) and lysed in lysis buffer (10× PBS, $10 \%$ Triton X-100, $1 \mathrm{M} \mathrm{MgCl}_{2}$, and 5\% cetyldimethylethylammonium bromide) and their survival was assessed by counting morphologically intact nuclei (Galehdar et al., 2010). For survival assay involving adenoviral infection (SHIF-1 $\alpha$ adenovirus), cells were infected with SHIF- $1 \alpha$ or GFP-expressing adenovirus. After $48 \mathrm{~h}$, cultures were treated with $20 \mu \mathrm{M} \mathrm{MPP}^{+}$for $48 \mathrm{~h}$ and fixed with $4 \%$ paraformaldehyde. Then nuclei were stained with Hoechst $33258(0.25 \mu \mathrm{g} / \mathrm{ml})$ to assess nuclear morphology. The survival percentage represents the ratio of GFPexpressing cells with morphologically intact nucleus to the total number of GFP-expressing neurons (Aleyasin et al., 2004). To assess cell survival using 3-(4,5-dimethylthiazol-2-yl)-2,5-diphenyltetrazolium bromide (MTT) methodology, cortical neurons plated for $48 \mathrm{~h}$ were treated with $0.1 \mathrm{~mm}$ dimethyloxallyl glycine (DMOG) or DMSO for $2 \mathrm{~h}$. Cells were then incubated with $20 \mu \mathrm{M} \mathrm{MPP}{ }^{+}$for $48 \mathrm{~h}$. Ten microliters of $12 \mathrm{~mm}$ MTT was added to $100 \mu \mathrm{l}$ of media in each well and incubated at $37^{\circ} \mathrm{C}$ for $4 \mathrm{~h}$. The media was discarded and cells were exposed to $100 \mu \mathrm{l}$ of MTT solvent for $15 \mathrm{~min}$. Cell viability was then assessed by measuring absorbance at $570 \mathrm{~nm}$. The survival percentage was calculated as the ratio of absorbance of all wells versus DMSO-treated wells from the same embryo, multiplied by 100 .

Lymphoblasts. Lymphoblasts, obtained from healthy individuals or patients with L166P mutation or deletion of exons $1-5$, were cultured in RPMI 1640 medium supplemented with $10 \% \mathrm{FCS}$ and incubated at $37^{\circ} \mathrm{C}$, $5 \% \mathrm{CO}_{2}$ (Macedo et al., 2003). They were treated as described in the figure legends.

Statistical analysis. Statistically significant differences were determined with ANOVA and post hoc Tukey's test or Student's $t$ test (when the comparison was between two groups) on results obtained from three independent experiments. Data were shown as mean \pm SEM, and significance was denoted by one asterisk where $p<0.05$, two asterisks where $p<0.01$, and three asterisks where $p<0.001$.

\section{Results}

\section{Identification of VHL as a DJ-1-interacting protein}

To identify upstream regulators or downstream effectors for DJ-1 that might be involved in the intracellular signaling pathways in disease models, we searched for cellular proteins that are associated with DJ-1 using a mass spectrometric strategy. This screen 
A

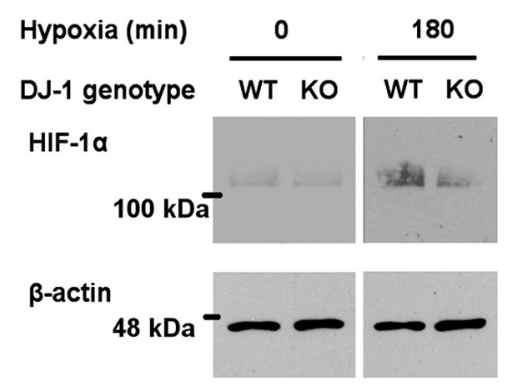

B

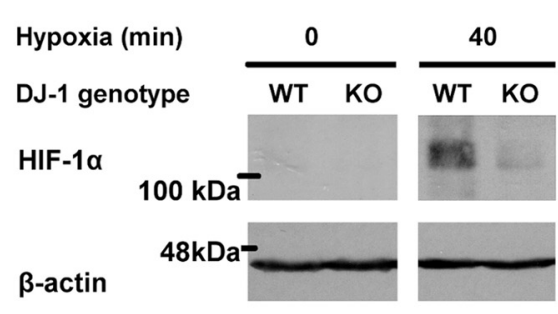

C

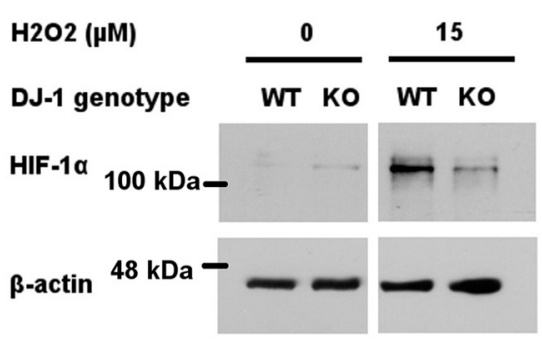

D

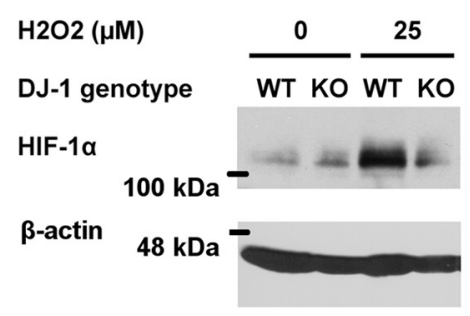

$\mathbf{E}$

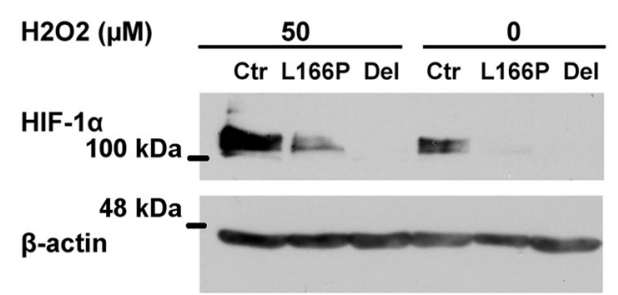

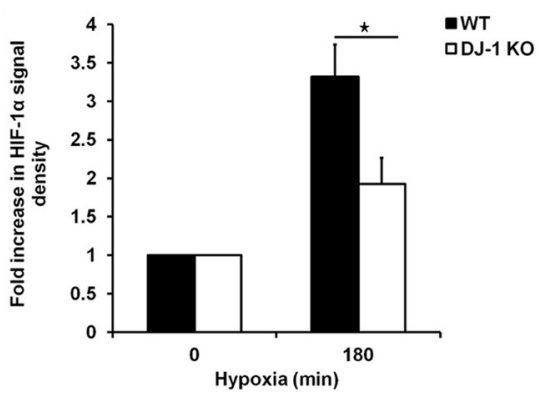
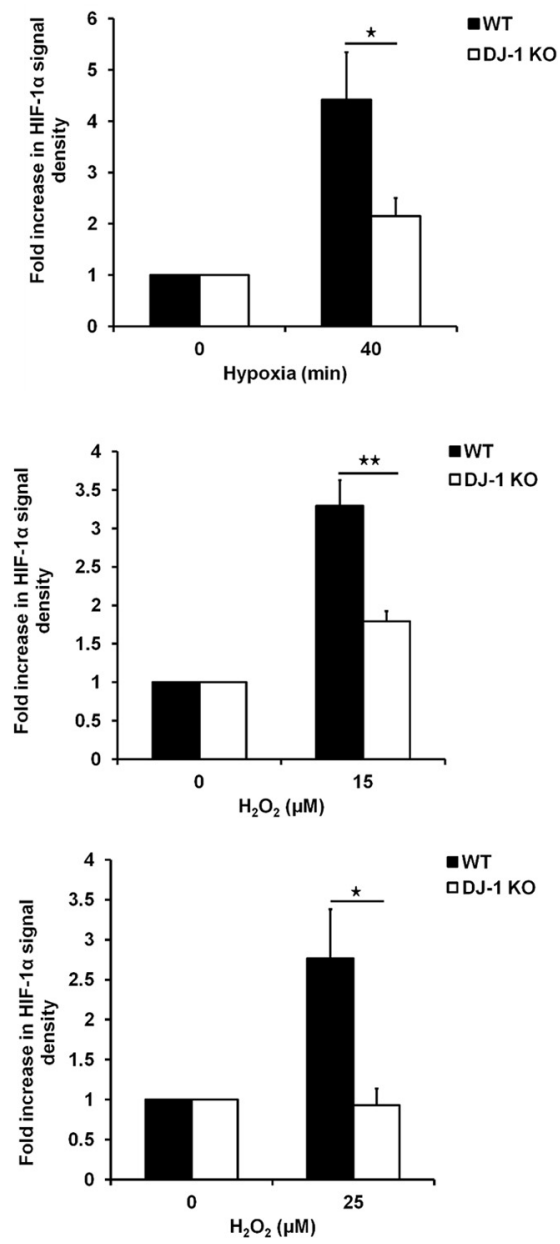

Figure 2. Functional link between DJ-1 and VHL. $\boldsymbol{A}, \boldsymbol{B}$, WT or DJ-1 $\mathrm{KO}$ cortical neurons $(\boldsymbol{A})$ or MEFs $(\boldsymbol{B})$ were incubated in normal condition or in hypoxia (1\% oxygen) for 180 min (neurons) or $40 \mathrm{~min}$ (MEFs). C, Cortical neurons were treated with $15 \mu \mathrm{M} \mathrm{H} \mathrm{H}_{2}$ for $2 \mathrm{~h}$. D. WT and DJ-1 KO MEFs were also exposed to 0 or $25 \mu \mathrm{m} \mathrm{H} \mathrm{H}_{2} \mathrm{O}_{2}$ for $24 \mathrm{~h}$. Cells were lysed and HIF- $1 \alpha$ protein level was assessed with Western blot using HIF-1 $\alpha$ antibody. Densitometry analysis of HIF-1 $\alpha$ protein for each experiment is demonstrated in the right side of each panel. Data are the mean \pm SEM from three independent experiments. ${ }^{*} p<0.05 ;{ }^{* *} p<0.01$, ANOVA with Tukey's post-test. $\boldsymbol{E}$, Lymphoblasts extracted from two PD cases, one with a deletion in DJ-1 (Del) and one with a point mutation in DJ-1 (L166P), or from control (Ctr) individual were exposed to $50 \mu$ m hydrogen peroxide for $24 \mathrm{~h}$ and their HIF- $1 \alpha$ response was examined with Western blot analysis using HIF- $1 \alpha$ antibody. 
A Hypoxia (min)
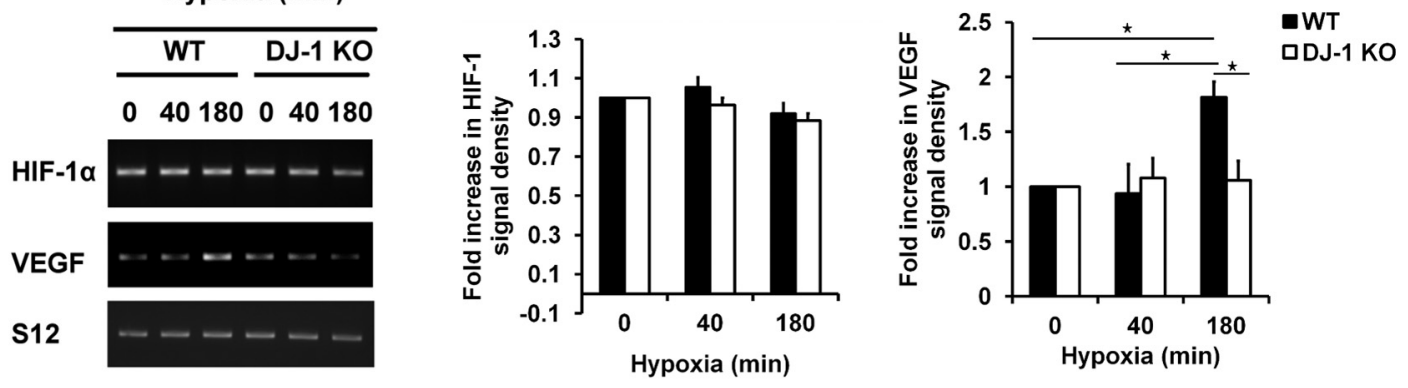

B
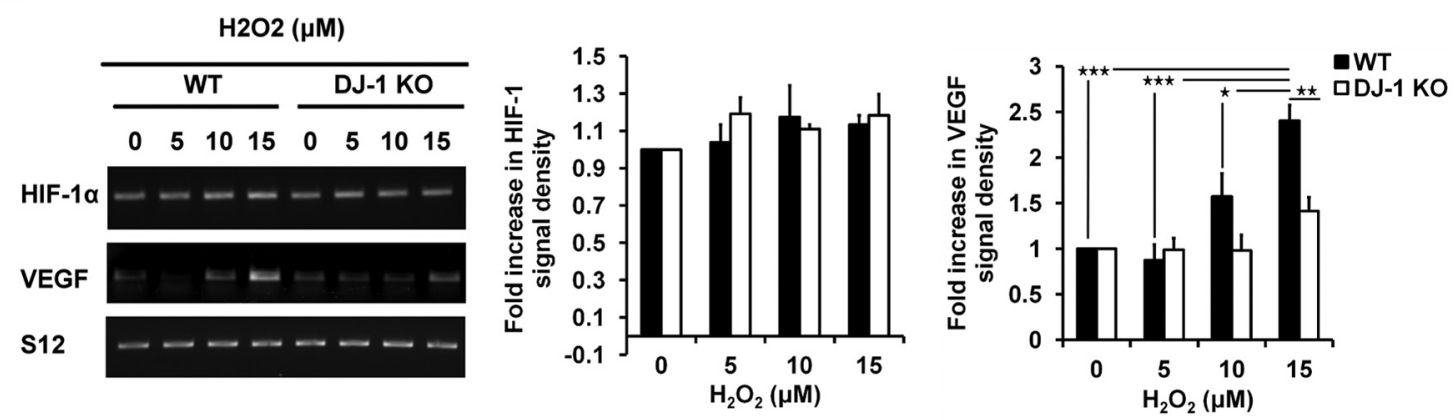

C
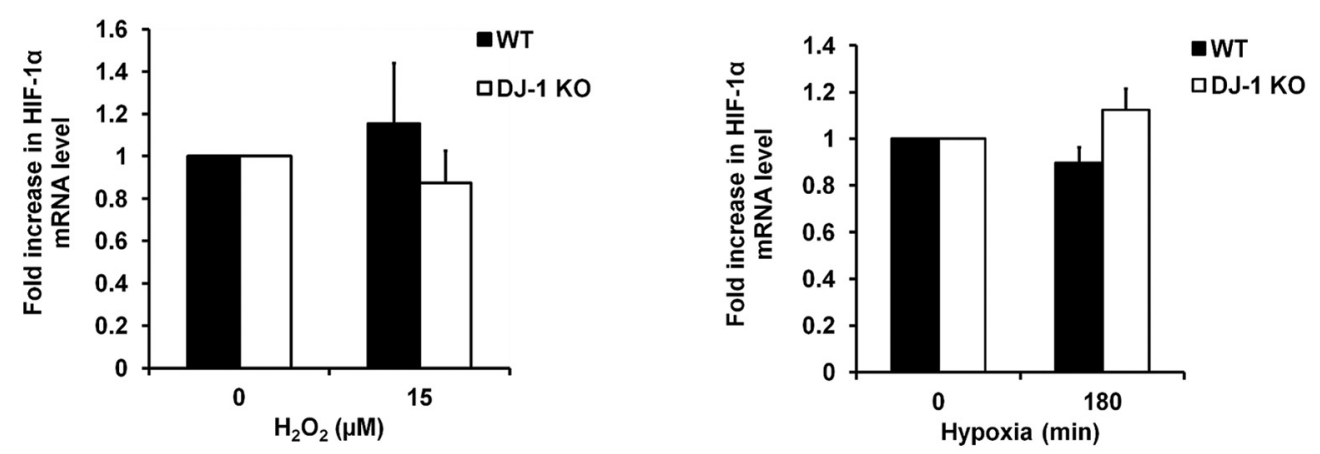

D
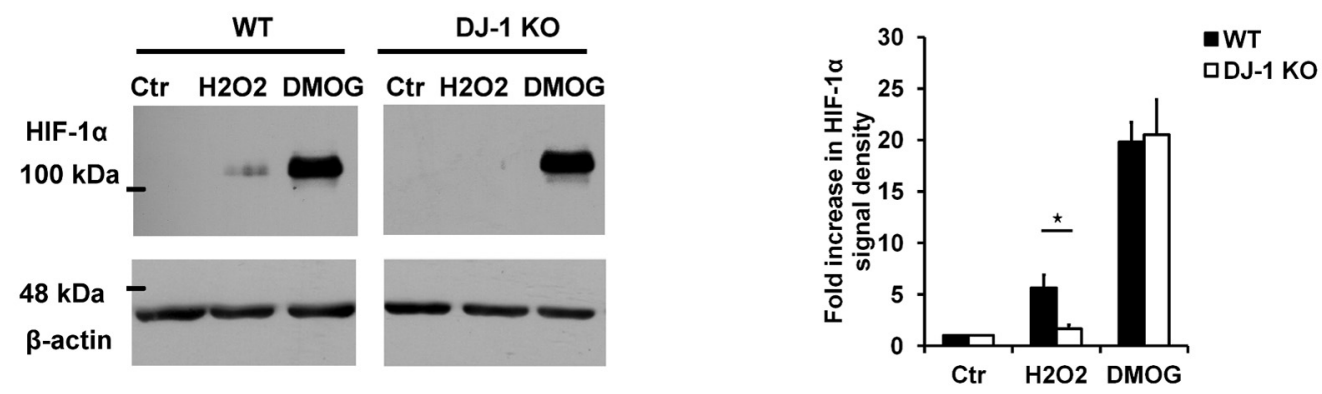

Figure 3. HIF-1 $\alpha$ expression is equal in DJ-1 WT and KO neurons and its response is VHL dependent. $\boldsymbol{A}, \boldsymbol{B}$, WT or DJ-1 K0 cortical neurons were exposed to hypoxia for 40 and 180 min ( $\boldsymbol{A})$ or to different concentrations of $\mathrm{H}_{2} \mathrm{O}_{2}(0,5,10$, and $15 \mu \mathrm{m})$ for $2 \mathrm{~h}(\boldsymbol{B})$. HIF- $1 \alpha$ transcripts were amplified by RT-PCR. The densitometry analysis of each experiment is demonstrated in the middle and right panels. C, HIF- $1 \alpha$ mRNA levels from WT or DJ-1 KO cortical neurons exposed to oxidative stress (left, 0 and $15 \mu \mathrm{m}$ for $2 \mathrm{~h}$ ) and hypoxia (right, 0 and 180 min) was also analyzed using qRT-PCR. D, WT and DJ- $1 \mathrm{KO}$ cortical neurons were treated with either $15 \mu \mathrm{M} \mathrm{H} \mathrm{H}_{2} \mathrm{O}_{2}$ for $2 \mathrm{~h}$ or $1 \mathrm{~mm} \mathrm{DMOG}$ for $3 \mathrm{~h}$. HIF- $1 \alpha$ level was assessed by Western blot using HIF- $1 \alpha$ antibody. The densitometry analysis is demonstrated in the right panel. Each bar is the mean \pm SEM from three independent experiments. ${ }^{*} p<0.05 ;{ }^{* *} p<0.01 ;{ }^{* *} p<0.001$ ANOVA.

was previously described in detail (Ewing et al., 2007). Briefly, 407 proteins were selected as baits, based on their reported functions in several pathologic conditions, such as diabetes, cancer, and obesity. These proteins were purified from human cell lysate, and their coprecipitated proteins were identified using mass spectrometry. VHL was one of the baits and analysis of the dataset suggested DJ-1 as one of its interacting candidates with the interaction confidence score of 0.31 .

We confirmed the physical interaction of DJ-1 and VHL proteins in SH-SY5Y cells by immunoprecipitating VHL using VHL antibody and mouse IgG-conjugated beads and probing for endogenous DJ-1 (Fig. 1A). We observed that endogenous DJ-1 was 
A

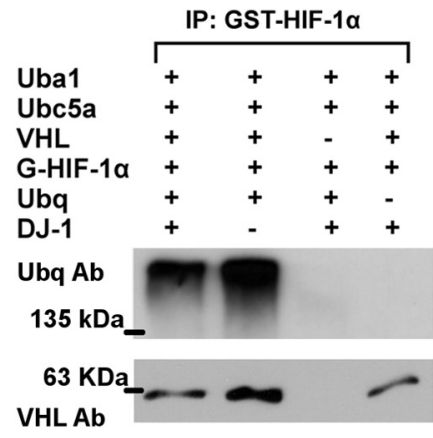

B

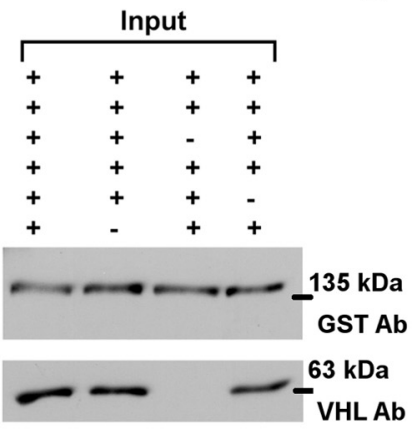

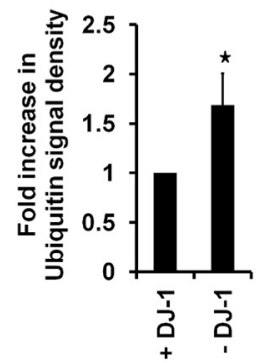

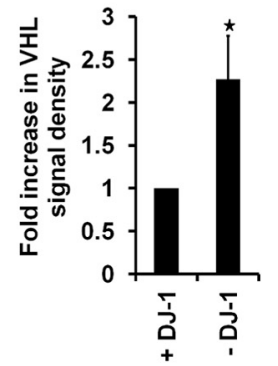

C

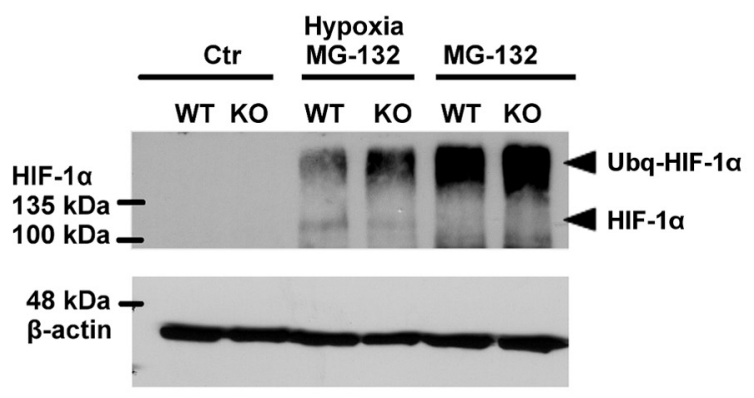

E

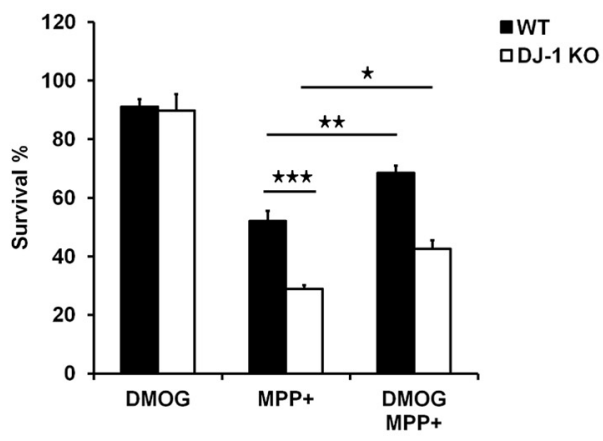

G

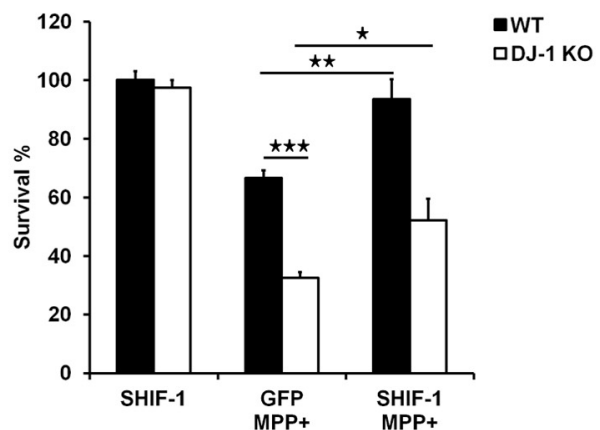

D

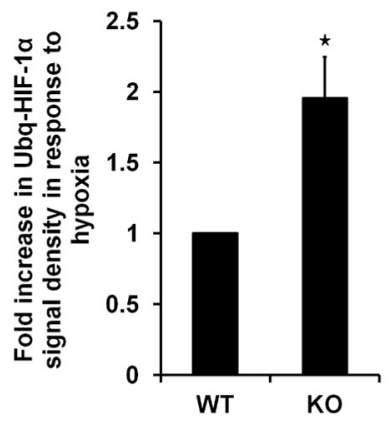

F

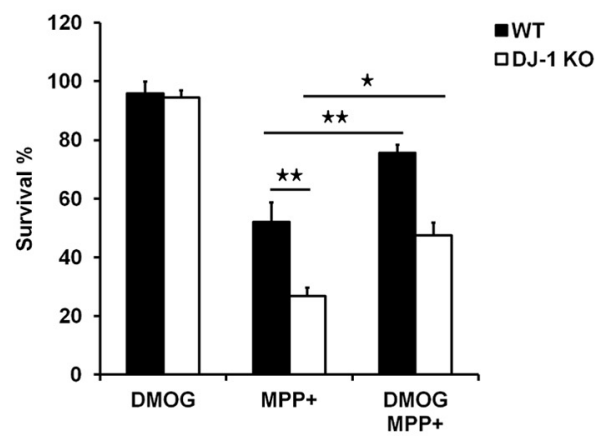

H
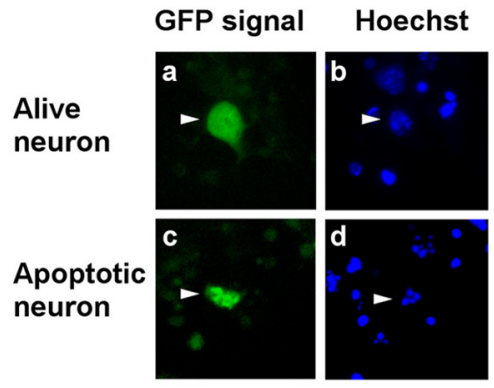

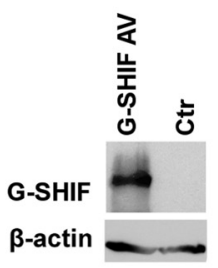

Figure 4. HIF-1 $\alpha$ ubiquitination is regulated by DJ-1 and HIF-1 overexpression protects neurons against MPP ${ }^{+}$. $\boldsymbol{A}, \boldsymbol{B}$, In vitro VHL ubiquitination assay was performed by incubating GST-HIF- $1 \alpha$ protein with the components of its ubiquitination pathway, including $\mathrm{hUBA1}$, $\mathrm{hUBC5A}$, and VHL complex, in presence or absence of DJ-1 protein, at $30^{\circ} \mathrm{C}$ for $2 \mathrm{~h}$. Groups without VHL or ubiquitin were used as controls. After reaction, GST-HIF-1 $\alpha$ (G-HIF-1 $\alpha$ ) was precipitated from the assay mixture with glutathione Sepharose beads, and its ubiquitination level and ability to interact with VHL were assessed by Western blot analysis using ubiquitin and VHL antibodies respectively. Total content of VHL and GST-HIF- $1 \alpha$ in each reaction, before starting ubiquitination, is shown as input. Densitometry analysis of ubiquitination and VHL-HIF- $1 \alpha$ interaction is shown in the middle and right panels. $\mathbf{C}, \mathbf{D}$, In vivo ubiquitination of HIF- $1 \alpha$ was assessed by stabilizing ubiquitinated HIF- $1 \alpha$ (Ubq-HIF-1 $\alpha$ ) in WT or DJ-1 KO MEFs treated with MG-132 (20 $\mu \mathrm{m}$ for $1 \mathrm{~h}$ ) and exposed to hypoxia ( $1 \mathrm{~h}$ ). HIF- $1 \alpha$ levels were assessed by Western blot analysis using HIF- $1 \alpha$ antibody. Quantification of Ubq-HIF- $1 \alpha$ was performed by normalizing the signal density of Ubq-HIF- $1 \alpha$ from hypoxia plus MG- 132 of each genotype to that of MG-132 of the same genotype, and then to the signal density of WT in MG-132-plus-hypoxia group. $E$, $F$, Primary cortical neurons derived from DJ- 1 KO or WT mouse embryos were pretreated with DMOG for $2 \mathrm{~h}$ and then treated with (Figure legend continues.) 
coimmunoprecipitated with endogenous VHL. In addition, to examine the potential effects of oxidative stress on this interaction, we treated FLAG-VHL-GFP-expressing SH-SY5Y cells with $25 \mu \mathrm{M} \mathrm{H}_{2} \mathrm{O}_{2}$, immunoprecipitated FLAG-VHL-GFP by FLAG antibody, and analyzed the immune complexes by Western blot. Interestingly, our results show an increase in interaction affinity between VHL and DJ-1 in response to oxidative stress (Fig. 1B).

\section{DJ-1 regulates HIF-1 $\alpha$ stability}

To explore the functional consequences of this interaction, we initially explored whether VHL may regulate DJ-1 protein levels. Utilizing WT, VHL-overexpressing, or VHL-deficient renal cell carcinoma (RCC) cells, we initially demonstrated that DJ-1 levels were not affected by modulation of VHL (data not shown). Accordingly, we next examined the converse: the potential regulatory role of DJ-1 on VHL activity. It is well established that VHL increases the proteolysis of HIF- $1 \alpha$ through a ubiquitinationdependent process (Maxwell et al., 1999; Kamura et al., 2000). Thus, we examined HIF- $1 \alpha$ levels, as an indicator of VHL activity, in response to hypoxia and oxidative stress in DJ-1-deficient murine neurons and MEFs. WT and knock-out (KO) cells were incubated under hypoxic ( $1 \%$ oxygen) or normoxic conditions. As Figure $2 A$ shows, HIF- $1 \alpha$ levels are decreased in hypoxiatreated $D J-1 \mathrm{KO}$ cortical neurons compared with WT controls. Similar results were also observed using MEFs (Fig. 2B). WT and DJ-1 KO cells were also exposed to $\mathrm{H}_{2} \mathrm{O}_{2}$, and assessed for HIF- $1 \alpha$ protein levels. These results also show that DJ-1 modulates HIF- $1 \alpha$ stability in response to oxidative stress (Fig. 2C,D).

\section{HIF- $1 \alpha$ response is VHL dependent and controlled at post- translational level}

The difference observed with the HIF- $1 \alpha$ response in DJ-1 WT and DJ-1 KO cells could be VHL independent and controlled at the transcriptional level. To address this, we first assessed the HIF- $1 \alpha$ mRNA levels, using RT-PCR analysis, following oxidative or hypoxic conditions in DJ-1 WT and KO cortical neurons. As Figure $3 A, B$ shows, there is no change in HIF- $1 \alpha$ mRNA levels in either $D J-1$ WT or KO neurons in response to hypoxia or oxidative stress. These results were also confirmed with real-time qRT-PCR analyses (Fig. 3C).

We further explored the role of DJ-1 on HIF- $1 \alpha$-regulated gene expression by assessing whether the downstream HIF-1 target gene, VEGF, is altered with $D J-1$ deficiency. Consistent with lower HIF- $1 \alpha$ levels, the induction of VEGF mRNA was reduced with $D J-1$ loss (Fig. $3 A, B$ ).

If differences in HIF- $1 \alpha$ protein levels with $D J-1$ deficiency are VHL dependent, we would anticipate that inhibition of prolyl hydroxyase activity would bypass VHL-dependent regulation of HIF- $1 \alpha$. HIF- $1 \alpha$ levels, then, should be similar in both DJ-1 WT

\section{$\leftarrow$}

(Figure legend continued.) $\mathrm{MPP}^{+}(20 \mu \mathrm{M})$ for $48 \mathrm{~h}$. Neurons were either $(\boldsymbol{E})$ lysed and the intact nuclei were counted $(n=4)$ or $(\boldsymbol{F})$ assessed by MTT survival assay $(n=3)$. $\boldsymbol{G}$, Stable form of HIF- $1 \alpha$ (GFP-SHIF- $1 \alpha$ ) or GFP alone as control was overexpressed in WT and DJ-1 K0 cortical neurons by GFP-SHIF- $1 \alpha$ and GFP-expressing adenovirus. Cells were then exposed to $20 \mu \mathrm{M}$ $\mathrm{MPP}^{+}$for $48 \mathrm{~h}$ and their fixed nuclei were stained with Hoechst. $\boldsymbol{H}$, Their viability was examined by calculating the ratio of neurons with intact nuclei and GFP signal ( $a$ and $b$ ) to the total number of GFP-expressing cells $(n=3)$. $\boldsymbol{H}$, Left, Adenoviral expression of GFP-SHIF- $1 \alpha$ in cultured cortical neurons ( $\boldsymbol{H a}$ and $\boldsymbol{H c}$ ) and Hoechst staining to detect intact versus apoptotic nuclei ( $\boldsymbol{H b}$ and $\boldsymbol{H d}$ ). $\boldsymbol{H}$, Right, Detection of GFP-SHIF- $1 \alpha$ by Western blot, using HIF- $1 \alpha$ antibody, in RCC cells infected with GFP-SHIF- $1 \alpha$-expressing adenovirus. Each bar is the mean \pm SEM of three or four independent experiments. ${ }^{*} p<0.05 ;{ }^{* *} p<0.01 ;{ }^{* * *} p<0.001$ ANOVA test and Tukey's post-test. and $\mathrm{KO}$ cells. We tested this, using the prolyl hydroxylase inhibitor DMOG. Following this treatment, we could detect no gross difference in total HIF- $1 \alpha$ content between DJ-1 WT and KO neurons (Fig. 3D). Together, these results suggest that differences observed in the HIF- $1 \alpha$ levels in the presence or absence of DJ-1 is likely through regulation of the VHL/PHD-related pathways.

\section{DJ-1 negatively regulates VHL ubiquitin ligase activity}

We next asked whether DJ-1 may directly regulate VHLmediated ubiquitination activity. To investigate this possibility, we performed a VHL in vitro ubiquitination assay in the presence or absence of DJ-1. To isolate active VHL complex, RCC cells were infected with adenovirus expressing FLAG-VHL-GFP and then VHL was immunoprecipitated using FLAG antibody. Recombinant hUBA1 and hUBC5a served as ubiquitin-activating enzyme E1 and ubiquitin-conjugating enzyme E2, respectively. Finally, bacterially expressed recombinant human HIF- $1 \alpha$ (GSTHIF-1 $\alpha$ ), hydroxylated by VHL-deficient RCC cell (786-0) lysate, was used as substrate. All the above proteins were incubated with ubiquitin and ATP (Kamura et al., 2000) in presence or absence of bacterially expressed human DJ- 1 for 2 h. GST-HIF- $1 \alpha$ was then precipitated with glutathione Sepharose beads and analyzed by Western blotting with ubiquitin and VHL antibodies. As shown in Figure $4 A, B$, the presence of DJ-1 decreases the level of HIF- $1 \alpha$ ubiquitination. In addition, our data indicate that the presence of DJ-1 is associated with a weaker VHL-HIF- $1 \alpha$ interaction, consistent with the model that DJ-1 leads to reduced HIF- $1 \alpha$ ubiquitination. To further investigate these findings in vivo, ubiquitinated HIF- $1 \alpha$ (Ubq-HIF- $1 \alpha$ ) was stabilized by proteasome inhibitor MG-132 in oxygen-deprived MEFs. The amount of Ubq-HIF- $1 \alpha$ was assessed by Western blot analysis. As shown in Figure $4 C, D$ and in line with our in vitro results, the levels of Ubq-HIF-1 $\alpha$ are reduced in WT cells compared with DJ-1 KO lines. Together, these results suggest that DJ-1 reduces HIF- $1 \alpha$ ubiquitination by reducing interaction with VHL.

\section{HIF-1 rescues DJ-1-deficient neurons in an in vitro model of PD}

DJ-1-deficient neurons have been reported to be hypersensitive to oxidative stress induced by several agents, including $\mathrm{MPP}^{+}$ (Kim et al., 2005). If HIF- $1 \alpha$ is a downstream target of DJ- 1 in this death paradigm, we predicted that HIF- $1 \alpha$ stabilization could rescue $D J-1$ deficiency-mediated hypersensitivity to $\mathrm{MPP}^{+}$. We used cortical neurons since our biochemical studies above were performed in this system. $\mathrm{MPP}^{+}$can induce death in a number of nondopaminergic neuron types, including cortical and cerebellar granule neurons (Qu et al., 2007; Endo et al., 2009; Huang et al., 2010; Harbison et al., 2011; Wellejus et al., 2012; Sheline et al., 2013). We first tested our hypothesis using DMOG to induce HIF-1 $\alpha$ stabilization. Cultured DJ-1 WT or KO cortical neurons were pretreated with DMOG, treated with $\mathrm{MPP}^{+}(20 \mu \mathrm{M})$ for $48 \mathrm{~h}$, and lysed. Then the morphologically intact nuclei were counted. As Figure $4 E$ shows, DMOG rescues DJ-1-deficient neurons against $\mathrm{MPP}^{+}$. These results were also confirmed by MTT cell viability assay (Fig. $4 F$ ). We also investigated the protective effect of SHIF- $1 \alpha$ expression. SHIF- $1 \alpha$ contains point mutations that substitute alanine for proline residues in the oxygendegradable domain (P402A/P564A) leading to resistance to hydroxylation by PHD (Smith et al., 2005). As demonstrated in Figure $4 G$, adenoviral-mediated expression of GFP-SHIF- $1 \alpha$ also rescues $D J-1 \mathrm{KO}$ neurons against oxidative stress induced by $\mathrm{MPP}^{+}$. Figure $4 \mathrm{H}$ demonstrates the cellular expression of GFPSHIF- $1 \alpha$ in cultured cortical neurons. The ability of our viral 
vector to generate recombinant HIF- $1 \alpha$ protein was confirmed by Western blot analyses (Fig. $4 \mathrm{H}$, right).

\section{HIF- $1 \alpha$ stabilization in response to oxidative stress is reduced in $D J$-1-mutated PD patients}

To better relate our findings to human PD condition, we determined whether HIF- $1 \alpha$ protein levels differed in lymphoblasts cultured from DJ-1-related PD cases (Irrcher et al., 2010). The PD patients included two individuals with different mutations in DJ-1: one from an Italian family with a point mutation, replacing leucine 166 with proline (L166P); and the other from a Dutch family with a deletion mutation from exon 1 to 5 (Bonifati et al., 2003). We have previously reported that these lymphoblasts exhibit elevated mitochondrial fragmentation and disturbed autophagic markers when compared with unaffected individuals (Irrcher et al., 2010). To evaluate the potential effect of DJ-1 on HIF- $1 \alpha$ stabilization, lymphoblasts were treated with $50 \mu \mathrm{M}$ $\mathrm{H}_{2} \mathrm{O}_{2}$ or vehicle as control for $24 \mathrm{~h}$ and then the HIF- $1 \alpha$ accumulation was assessed by Western blot. As Figure $2 E$ shows, oxidative stress-induced HIF- $1 \alpha$ accumulation is significantly diminished in DJ-1-linked PD lymphoblast samples compared with control individual (Fig. 2E). These results confirm that the defective stress response of HIF- $1 \alpha$ observed in $D J-1$ WT and KO cells also occurs in DJ-1-associated PD cases.

\section{Discussion}

DJ-1 has been reported as a neuroprotective protein under oxidative and hypoxic conditions (Kim et al., 2005; Aleyasin et al., $2007,2010)$. The mechanisms through which DJ-1 manages oxidative damage are unclear. In a proteomic screen via a mass spectrometry analysis, we identified VHL protein as a DJ-1 interactor. The interaction of DJ-1 and VHL was further confirmed in immunoprecipitation studies. In conjunction with previous reports indicating a protective role of both DJ- 1 and the VHL target protein HIF- $1 \alpha$, we hypothesized that DJ-1 protects neurons against oxidative damage via inhibition of VHL-ubiquitination activity. Our present observations support this hypothesis. First, HIF- $1 \alpha$ levels in rodent cells (MEFs and neurons) under oxidative and/or hypoxic conditions are lower with $D J-1$ deficiency. This is not due to difference in transcription of HIF- $1 \alpha$. Second, in a direct assay of VHL ubiquitination activity using isolated components, we show that DJ-1 reduces ubiquitination of HIF$1 \alpha$. Third, stabilization of HIF- $1 \alpha$ both protects wild-type neurons and reverses the sensitivity to $\mathrm{MPP}^{+}$-induced neuronal death observed with $D J-1$ deficiency. Finally, we demonstrate that our observations in rodent cells also have relevance to human cells extracted from $D J$-1-related PD patients, where HIF- $1 \alpha$ response to oxidative stress is less than that of control samples. In this case, even basal levels of HIF- $1 \alpha$ appeared reduced in DJ-1 patient lymphoblasts, an observation not consistently observed in MEFs and murine neurons. This discrepancy may be due to the fact that basal HIF- $1 \alpha$ levels were significantly elevated in lymphoblasts compared with mouse cell types examined. Together, our results support a model by which regulation of VHL activity by DJ-1 mediates its survival properties.

The significance of our results is supported by the notion that the VHL and HIF- $1 \alpha$ have been implicated in a number of degenerative models. For example HIF- $1 \alpha$ signaling has been shown to be downregulated in SNc of PD cases (Elstner et al., 2011). In addition, accumulation of HIF- $1 \alpha$ or its downstream proteins, such as EPO and VEGF, results in reduction of MPTP toxicity in mice (Genc et al., 2002; Lee et al., 2009). They also have neuroprotective effects in ischemia (Sun et al., 2003; Kilic et al.,
2005). Given the notion that $D J-1$ deficiency sensitizes to neuronal damage in both toxin and stroke models of injury, our results link these observations by providing a mechanism through which DJ-1 regulates the VHL-HIF pathway to promote survival. However, it is important to note that DJ-1 may also have effects that are independent of HIF- $1 \alpha$.

Interestingly, DJ-1 has been reported to interact with a number of E3 ligases, such as Parkin, PIASx $\alpha$, TOPORS (topoisomerase 1 binding, arginine/serine-rich, E3 ubiquitin ligase), and TRAF6 (Takahashi et al., 2001; Shinbo et al., 2006; Xiong et al., 2009; Zucchelli et al., 2010). This suggests a common theme of action for DJ-1, although the functional significance of these interactions has never been clarified. It is therefore significant that we demonstrate the functional outcome of such interaction in the case of VHL. We suggest that regulation of VHL is directly through interaction with DJ-1 and interruption with VHL-HIF interaction. How this exactly occurs remains to be identified.

\section{References}

Aleyasin H, Cregan SP, Iyirhiaro G, O'Hare MJ, Callaghan SM, Slack RS, Park DS (2004) Nuclear factor- $\kappa$ B modulates the p53 response in neurons exposed to DNA damage. J Neurosci 24:2963-2973. CrossRef Medline

Aleyasin H, Rousseaux MW, Phillips M, Kim RH, Bland RJ, Callaghan S, Slack RS, During MJ, Mak TW, Park DS (2007) The Parkinson's disease gene DJ-1 is also a key regulator of stroke-induced damage. Proc Natl Acad Sci U S A 104:18748-18753. CrossRef Medline

Aleyasin H, Rousseaux MW, Marcogliese PC, Hewitt SJ, Irrcher I, Joselin AP, Parsanejad M, Kim RH, Rizzu P, Callaghan SM, Slack RS, Mak TW, Park DS (2010) DJ-1 protects the nigrostriatal axis from the neurotoxin MPTP by modulation of the AKT pathway. Proc Natl Acad Sci U S A 107:3186-3191. CrossRef Medline

Berra E, Benizri E, Ginouvès A, Volmat V, Roux D, Pouysségur J (2003) HIF prolyl-hydroxylase 2 is the key oxygen sensor setting low steady-state levels of HIF-1alpha in normoxia. EMBO J 22:4082-4090. CrossRef Medline

Bonifati V, Rizzu P, van Baren MJ, Schaap O, Breedveld GJ, Krieger E, Dekker MC, Squitieri F, Ibanez P, Joosse M, van Dongen JW, Vanacore N, van Swieten JC, Brice A, Meco G, van Duijn CM, Oostra BA, Heutink P (2003) Mutations in the DJ-1 gene associated with autosomal recessive early-onset parkinsonism. Science 299:256-259. CrossRef Medline

Elstner M, Morris CM, Heim K, Bender A, Mehta D, Jaros E, Klopstock T, Meitinger T, Turnbull DM, Prokisch H (2011) Expression analysis of dopaminergic neurons in Parkinson's disease and aging links transcriptional dysregulation of energy metabolism to cell death. Acta Neuropathol 122:75-86. CrossRef Medline

Endo R, Saito T, Asada A, Kawahara H, Ohshima T, Hisanaga S (2009) Commitment of 1-methyl-4-phenylpyrinidinium ion-induced neuronal cell death by proteasome-mediated degradation of p35 cyclin-dependent kinase 5 activator. J Biol Chem 284:26029-26039. CrossRef Medline

Ewing RM, Chu P, Elisma F, Li H, Taylor P, Climie S, McBroom-Cerajewski L, Robinson MD, O'Connor L, Li M, Taylor R, Dharsee M, Ho Y, Heilbut A, Moore L, Zhang S, Ornatsky O, Bukhman YV, Ethier M, Sheng Y et al. (2007) Large-scale mapping of human protein-protein interactions by mass spectrometry. Mol Syst Biol 3:89. Medline

Galehdar Z, Swan P, Fuerth B, Callaghan SM, Park DS, Cregan SP (2010) Neuronal apoptosis induced by endoplasmic reticulum stress is regulated by ATF4-CHOP-mediated induction of the Bcl-2 homology 3-only member PUMA. J Neurosci 30:16938-16948. CrossRef Medline

Genc S, Akhisaroglu M, Kuralay F, Genc K (2002) Erythropoietin restores glutathione peroxidase activity in 1-methyl-4-phenyl-1,2,5,6-tetrahydropyridine-induced neurotoxicity in C57BL mice and stimulates murine astroglial glutathione peroxidase production in vitro. Neurosci Lett 321:73-76. CrossRef Medline

Harbison RA, Ryan KR, Wilkins HM, Schroeder EK, Loucks FA, Bouchard RJ, Linseman DA (2011) Calpain plays a central role in 1-methyl-4phenylpyridinium (MPP+)-induced neurotoxicity in cerebellar granule neurons. Neurotox Res 19:374-388. CrossRef Medline

Huang E, Qu D, Zhang Y, Venderova K, Haque ME, Rousseaux MW, Slack RS, Woulfe JM, Park DS (2010) The role of Cdk5-mediated apurinic/ 
apyrimidinic endonuclease 1 phosphorylation in neuronal death. Nat Cell Biol 12:563-571. CrossRef Medline

Irrcher I, Aleyasin H, Seifert EL, Hewitt SJ, Chhabra S, Phillips M, Lutz AK, Rousseaux MW, Bevilacqua L, Jahani-Asl A, Callaghan S, MacLaurin JG, Winklhofer KF, Rizzu P, Rippstein P, Kim RH, Chen CX, Fon EA, Slack RS, Harper ME, et al. (2010) Loss of the Parkinson's disease-linked gene DJ-1 perturbs mitochondrial dynamics. Hum Mol Genet 19:3734-3746. CrossRef Medline

Johansen JL, Sager TN, Lotharius J, Witten L, Mørk A, Egebjerg J, Thirstrup K (2010) HIF prolyl hydroxylase inhibition increases cell viability and potentiates dopamine release in dopaminergic cells. J Neurochem 115:209219. CrossRef Medline

Kamura T, Sato S, Iwai K, Czyzyk-Krzeska M, Conaway RC, Conaway JW (2000) Activation of HIFlalpha ubiquitination by a reconstituted von Hippel-Lindau (VHL) tumor suppressor complex. Proc Natl Acad Sci U S A 97:10430-10435. CrossRef Medline

Kilic E, Kilic U, Soliz J, Bassetti CL, Gassmann M, Hermann DM (2005) Brain-derived erythropoietin protects from focal cerebral ischemia by dual activation of ERK-1/-2 and Akt pathways. FASEB J 19:2026-2028. Medline

Kim RH, Smith PD, Aleyasin H, Hayley S, Mount MP, Pownall S, Wakeham A, You-Ten AJ, Kalia SK, Horne P, Westaway D, Lozano AM, Anisman H, Park DS, Mak TW (2005) Hypersensitivity of DJ-1-deficient mice to 1-methyl-4-phenyl-1,2,3,6-tetrahydropyrindine (MPTP) and oxidative stress. Proc Natl Acad Sci U S A 102:5215-5220. CrossRef Medline

Lee DW, Rajagopalan S, Siddiq A, Gwiazda R, Yang L, Beal MF, Ratan RR, Andersen JK (2009) Inhibition of prolyl hydroxylase protects against 1-methyl-4-phenyl-1,2,3,6-tetrahydropyridine-induced neurotoxicity: model for the potential involvement of the hypoxia-inducible factor pathway in Parkinson disease. J Biol Chem 284:29065-29076. CrossRef Medline

Lonergan KM, Iliopoulos O, Ohh M, Kamura T, Conaway RC, Conaway JW, Kaelin WG Jr (1998) Regulation of hypoxia-inducible mRNAs by the von Hippel-Lindau tumor suppressor protein requires binding to complexes containing elongins B/C and Cul2. Mol Cell Biol 18:732-741. Medline

Lonser RR, Glenn GM, Walther M, Chew EY, Libutti SK, Linehan WM, Oldfield EH (2003) von Hippel-Lindau disease. Lancet 361:2059-2067. CrossRef Medline

Macedo MG, Anar B, Bronner IF, Cannella M, Squitieri F, Bonifati V, Hoogeveen A, Heutink P, Rizzu P (2003) The DJ-1L166P mutant protein associated with early onset Parkinson's disease is unstable and forms higher-order protein complexes. Hum Mol Genet 12:2807-2816. CrossRef Medline

Maxwell PH, Wiesener MS, Chang GW, Clifford SC, Vaux EC, Cockman ME,
Wykoff CC, Pugh CW, Maher ER, Ratcliffe PJ (1999) The tumour suppressor protein VHL targets hypoxia-inducible factors for oxygendependent proteolysis. Nature 399:271-275. CrossRef Medline

Qu D, Rashidian J, Mount MP, Aleyasin H, Parsanejad M, Lira A, Haque E, Zhang Y, Callaghan S, Daigle M, Rousseaux MW, Slack RS, Albert PR, Vincent I, Woulfe JM, Park DS (2007) Role of Cdk5-mediated phosphorylation of Prx2 in MPTP toxicity and Parkinson's disease. Neuron 55:37-52. CrossRef Medline

Sheline CT, Zhu J, Zhang W, Shi C, Cai AL (2013) Mitochondrial inhibitor models of Huntington's disease and Parkinson's disease induce zinc accumulation and are attenuated by inhibition of zinc neurotoxicity in vitro or in vivo. Neurodegener Dis 11:49-58. CrossRef Medline

Shinbo Y, Niki T, Taira T, Ooe H, Takahashi-Niki K, Maita C, Seino C, Iguchi-Ariga SM, Ariga H (2006) Proper SUMO-1 conjugation is essential to DJ-1 to exert its full activities. Cell Death Differ 13:96-108. CrossRef Medline

Smith K, Gunaratnam L, Morley M, Franovic A, Mekhail K, Lee S (2005) Silencing of epidermal growth factor receptor suppresses hypoxiainducible factor-2-driven VHL-/- renal cancer. Cancer Res 65:52215230. CrossRef Medline

Sun Y, Jin K, Xie L, Childs J, Mao XO, Logvinova A, Greenberg DA (2003) VEGF-induced neuroprotection, neurogenesis, and angiogenesis after focal cerebral ischemia. J Clin Invest 111:1843-1851. CrossRef Medline

Taira T, Saito Y, Niki T, Iguchi-Ariga SM, Takahashi K, Ariga H (2004) DJ-1 has a role in antioxidative stress to prevent cell death. EMBO Rep 5:213218. CrossRef Medline

Takahashi K, Taira T, Niki T, Seino C, Iguchi-Ariga SM, Ariga H (2001) DJ-1 positively regulates the androgen receptor by impairing the binding of PIASx alpha to the receptor. J Biol Chem 276:37556-37563. CrossRef Medline

Tanimoto K, Makino Y, Pereira T, Poellinger L (2000) Mechanism of regulation of the hypoxia-inducible factor-1 alpha by the von Hippel-Lindau tumor suppressor protein. EMBO J 19:4298-4309. CrossRef Medline

Wellejus A, Elbrønd-Bek H, Kelly NM, Weidner MS, Jørgensen SH (2012) 4-iodophenyl isothiocyanate: a neuroprotective compound. Restor Neurol Neurosci 30:21-38. Medline

Xiong H, Wang D, Chen L, Choo YS, Ma H, Tang C, Xia K, Jiang W, Ronai Z, Zhuang X, Zhang Z (2009) Parkin, PINK1, and DJ-1 form a ubiquitin E3 ligase complex promoting unfolded protein degradation. J Clin Invest 119:650-660. CrossRef Medline

Zucchelli S, Codrich M, Marcuzzi F, Pinto M, Vilotti S, Biagioli M, Ferrer I, Gustincich S (2010) TRAF6 promotes atypical ubiquitination of mutant DJ-1 and alpha-synuclein and is localized to Lewy bodies in sporadic Parkinson's disease brains. Hum Mol Genet 19:3759-3770. CrossRef Medline 